\title{
The effects of benzoic acid and essential oil compounds in combination with protease on the performance of chickens
}

\author{
I.A. Giannenas ${ }^{1}$, C.P. Papaneophytou ${ }^{2}$, E. Tsalie ${ }^{3}$, E. Triantafillou ${ }^{4}$, D. Tontis ${ }^{3}$ and G.A. Kontopidis ${ }^{2}$ \\ ${ }^{1}$ Aristotle University of Thessaloniki, School of Veterinary Medicine, Laboratory of Nutrition \\ 54124 Thessaloniki, Greece, \\ University of Thessaly, Veterinary Faculty, ${ }^{2}$ Laboratory of Biochemistry, ${ }^{3}$ Laboratory of Pathology, 43100 Karditsa, Greece \\ ${ }^{4}$ Military Veterinary Training and Nursing Centre, 41334 Larisa, Thessaly, Greece
}

KEYWORDS: benzoic acid, essential oils, protease, performance, intestinal microbiota, broiler chickens

Received: 10 October 2013

Revised: 7 December 2013

Accepted: 4 March 2014

\begin{abstract}
Experiments were conducted to study the effect of benzoic acid and of essential oil blends in combination with protease on the growth performance of broiler chickens. In the first trial, the birds were divided into three dietary treatments. The control group was fed a basal diet, while the other two groups were given benzoic acid at 300 and $1000 \mathrm{mg} \cdot \mathrm{kg}^{-1}$, respectively. Growth performance was not affected by benzoic acid inclusion. The $\mathrm{pH}$ values of the caecal content decreased following benzoic acid supplementation, while no differences were noticed in the $\mathrm{pH}$ of the crop, gizzard, ileum and rectum contents. Following benzoic acid supplementation, lactic acid bacteria populations increased in the caecum, and coliform bacteria, decreased. In the second trial, the birds were divided into three dietary treatments. The controls were fed a basal diet, while the other two groups were given thymol and a mixture of essential oil compounds (30 $\mathrm{mg} \cdot \mathrm{kg}^{-1}$ ). The dietary inclusion of the mixture of essential oil compounds enhanced growth performance compared with the other groups $(P<0.05)$, increased lactic acid bacteria populations, and decreased the coliform bacteria population in the caecum. In the third trial, the control group was fed the basal diet, while the other group was given a diet with similar ingredients and containing more benzoic acid and a mixture of essential oils, protease, and less protein and amino acids. In vitro tests showed that addition of benzoic acid, the mixture of essential oils and protease reduced buffering capacity compared with control feed and simulation experiments revealed that the protease increased protein extraction, hydrolysis and digestion. The combination of benzoic acid, essential oils and protease effectively improved weight gain and the feed conversion ratio compared with the control, as well as villus height, lactic acid bacteria counts, and reduced coliform bacteria counts compared with the control group. Finally, it was demonstrated for the first time that the novel, acid-stable protease increases protein solubilization, hydrolysis and digestion in an in vitro simulation model.
\end{abstract}

Corresponding author:

e-mail: igiannenas@vet.auth.gr bial growth promoters (AGPs) from poultry diets in the European Union, concerns over food safety, environmental contamination, and general health risks increased, and the search for growth-promoting and immune system-strengthening alternatives is necessary (Franz et al., 2010). Considerable effort has been de- 
voted towards developing alternatives to antibiotics. Organic acids and herbal extracts are two important alternatives of great interest to the poultry industry.

Organic acids and their salts could be a potential alternative feed supplement to antibiotic growth promoters. Benzoic acid, a well-known preservative, has attracted wide research interest due to its antibacterial and antifungal properties. The efficacy of organic acids as a replacement for antibiotic growth promoters in broiler chickens has not been adequately demonstrated, however, and relevant information is rather limited. While antibiotics inhibit microbial growth in general, organic acids can stabilize gastric $\mathrm{pH}$ and favour domination of beneficial, rather than harmful, microorganisms in the digestive tract, thus enhancing growth and feed efficiency (Partanen and Mroz, 1999). Hence, organic acids are widely used by the feed industry in earlyweaned pigs and as effective preservatives, but their use in broiler chickens as a means of controlling enteric bacteria and improving feed utilization has not been widely investigated (Eidelsburger and Kirchgessner, 1994). It was previously demonstrated that benzoic acid at a $1.2 \%$ inclusion level in broiler feed improved weight gain and also suppressed some microbes, and improved growth performance and gut health of broilers (Amaechi and Anueyiagu, 2012).

In addition to organic acids, plant extracts offer a unique opportunity in this regard (Giannenas et al., 2005), as many plants produce secondary metabolites, such as saponins, tannins and polyphenols, which have antimicrobial properties. Essential oils (EO), plant extracts and certain herbs might be interesting alternative feed supplements to antibiotic growth promoters (Franz et al., 2010). In recent years, many herbal plants such as rosemary, sage, thyme, oregano and tea or their extracts have attracted wide research interest due to their antioxidative, antibacterial and antifungal properties (Giannenas et al., 2003, 2005) that are attributed to a great variety of phenolic compounds occurring in these plants. Moreover, thymol has intrinsic bioactivities on animal physiology and metabolism and, therefore, could have antioxidant activity in chicken meat when supplemented in the feed (Giannenas et al., 2005).

The antimicrobial properties of EO have encouraged their use as a natural replacement for antibiotic growth promoters in animal feeds. In addition to the positive effects of EO against the colonization and proliferation of pathogenic bacteria, EOs have been shown to improve nutrient digestibility and broiler performance (Amerah et al., 2011). Recent studies have highlighted the potential benefit of combining EO and carbohydrase enzymes on broiler performance and nutrient digestibility (Amerah et al., 2011). Although most of these more natural approaches have already been used in combination with in-feed antibiotics, their efficacy as the only dietary growth promoting additives has not been yet fully established (Franz et al., 2010).

The poultry industry readily accepts enzymes as a standard dietary component, especially in wheat and barley-based rations (Acamovic, 2001). The use of enzymes in broiler chicken nutrition is well established in the case of energy and phosphorus utilization (Leeson and Caston, 1996). Some of the enzymes that have been used over the past several years or have potential for use in the feed industry include cellulase (ß-glucanases), xylanases and associated enzymes, phytases, proteases, lipases and galactosidases. The use of proteases in the past was not successful, due to inconsistent results and high degradability rate (Acamovic, 2001). Little information is available on the effects of combining EOs with benzoic acid and protease on poultry health and performance.

This study was conducted to investigate the effects of benzoic acid, thymol, a mixture of EOs, and the combination of EOs with benzoic acid on the growth performance of broiler chickens. Additionally, it is hypothesized that the addition of a protease to the feeds can increase both protein extraction and digestion.

\section{Material and methods}

The trial protocol was approved by the Institutional Committee of The Veterinary Faculty of the University of Thessaly. Throughout the trial, the chickens were handled according to the principles for the care of animals in experimentation.

\section{Bird housing and management}

A series of three growth experiments was performed in a commercial broiler chicken farm in Edessa (Greece). All groups were housed on wood shaving litter. The stocking density was 18 birds per $1 \mathrm{~m}^{2}$. During the trials, commercial breeding and management procedures were employed, natural and artificial light was provided on a basis of $23 \mathrm{~h}$ for the first 2 days, $16 \mathrm{~h}$ from day 3 to day 14,21 $\mathrm{h}$ from day 15 to the slaughter days, and ambient temperature was controlled. Feed and drinking water were offered to all birds ad libitum throughout the experiment.

\section{Feeding trials}

The composition of the basal diet for the first and second trials is presented in Table 1, while the composition of the diets for the third trial is presented in Table 2. All feeds were in mash form and 
Table 1. Composition of basal diets (Experiments 1 and 2$), \mathrm{g} \cdot \mathrm{kg}^{-1}$

\begin{tabular}{lrr}
\hline Indices & $1-14 \mathrm{~d}$ & $15-42 \mathrm{~d}$ \\
\hline Ingredients & & \\
$\quad$ maize & 600.0 & 635.0 \\
soyabean meal, $47.4 \mathrm{CP}$ & 316.0 & 276.0 \\
soyabean oil & 25.0 & 15.0 \\
coconut fat & 18.0 & 35.0 \\
limestone & 11.0 & 11.0 \\
dicalcium phosphate & 8.0 & 7.0 \\
sodium bicarbonate & 2.0 & 1.0 \\
vitamins, amino acids and mineral premix & 20.0 & 20.0 \\
Calculated & & \\
$\quad$ crude protein, $\mathrm{g} \cdot \mathrm{kg}^{-1}$ & 220 & 210 \\
metabolizable energy, $\mathrm{kcal}^{-} \cdot \mathrm{kg}^{-1}$ & 3100 & 3180 \\
\hline
\end{tabular}

${ }^{1}$ supplying per kg feed: IU: vit. A-12,000, vit. $D_{3}-5,000$; mg: vit. E-80, vit. $K-7$, thiamin -5 , riboflavin -6 , pyridoxine -6 , vit. $B_{12}-0.02$, niacin -60 , pantothenic acid -15 , folic acid -1.5 , biotin -0.25 , vit. $\mathrm{C}-10$, choline chloride - 500, $\mathrm{Zn}-100, \mathrm{Mn}-120, \mathrm{Fe}-20, \mathrm{Cu}-15$, Co $-0.2, \mathrm{I}-1$, Se -0.3 ; g: amino acids (lysine+methionine) $-2,9$, phytase -0.11

Table 2 Composition of diets (Experiment 3$), \mathrm{g} \cdot \mathrm{kg}^{-1}$

\begin{tabular}{|c|c|c|c|c|}
\hline \multirow{2}{*}{ Indices } & \multicolumn{2}{|l|}{ Control } & \multicolumn{2}{|c|}{ BMEO + PRA } \\
\hline & $1-14 d$ & $15-42 d$ & $1-14 d$ & $15-42 d$ \\
\hline \multicolumn{5}{|l|}{ Ingredients } \\
\hline maize & 603.0 & 635.0 & 629.0 & 665.0 \\
\hline soyabean meal, 46.8 & 316.0 & 276.0 & 280.0 & 250.0 \\
\hline soyabean oil & 25.0 & 15.0 & 25.0 & 11.0 \\
\hline coconut fat & 18.0 & 35.0 & 15.0 & 35.0 \\
\hline limestone & 11.0 & 11.0 & 11.0 & 11.0 \\
\hline dicalcium phosphate & 8.0 & 7.0 & 8.0 & 7.0 \\
\hline sodium bicarbonate & 2.0 & 1.0 & 2.0 & 1.0 \\
\hline $\begin{array}{l}\text { vitamins, amino acids and } \\
\text { mineral premix }{ }^{1}\end{array}$ & 20.0 & 20.0 & 20.0 & 20.0 \\
\hline \multicolumn{5}{|l|}{ Calculated } \\
\hline crude protein, $\mathrm{g} \cdot \mathrm{kg}^{-1}$ & 221 & 210 & 215 & 202 \\
\hline metabolizable energy, $\mathrm{kcal} \cdot \mathrm{kg}^{-1}$ & 13100 & 3180 & 3100 & 3180 \\
\hline
\end{tabular}

did not contain any anticoccidial or antimicrobial growth-promoting agent. All birds were weighed individually at the time of their placing into the poultry house and weekly thereafter. All birds were vaccinated against Marek disease after hatching, and against Newcastle disease, infectious bronchitis, and Gumboro during the second week of life. Feed consumption within each group was recorded during the experimental periods and the feed conversion ratio was calculated. Mortality was also recorded daily.

Experiment 1. This trial was conducted with 180 one-day-old Ross 308 female broiler chickens that were randomly allocated into three groups with six replicates per group. During the feeding period that lasted 42 days, one group was fed a basal commercial diet, the other groups were fed the same diet supplemented with either 300 or $1000 \mathrm{mg} \cdot \mathrm{kg}^{-1}$ benzoic acid (B300 and B1000, respectively). The ben- zoic acid used in this study is a commercial product named VevoVitall ${ }^{\circledR}$ containing pure benzoic acid (DSM Nutritional Products, Basel, Switzerland).

Experiment 2. In this trial, a total of 180 oneday-old Ross 308 female broiler chicks was randomly allocated into three groups with six replicates per group. During the feeding period (42 days), one group was fed on the basal commercial diet, the other groups on the same diet supplemented with either $30 \mathrm{mg} \cdot \mathrm{kg}^{-1}$ thymol (T30) or $30 \mathrm{mg} \cdot \mathrm{kg}^{-1}$ of a mixture of essential oils (MEO30). The mixture of essential oils is a commercial product (CRINA Poultry-CP; DSM Nutritional Products Ltd., Basel, Switzerland) containing thymol $\geq 10 \%$, eugenol $\geq$ $0.5 \%$, piperine $\geq 0.05 \%$ and other flavouring substrates $\leq 0.6 \%$.

Experiment 3. A total of 120 one-day-old Ross 308 female broiler chicks was randomly allocated into two groups with six replicates per group. During the feeding period that lasted 42 days, the birds were fed a basal commercial diet (control-C3), or the same diet supplemented with $300 \mathrm{mg} \cdot \mathrm{kg}^{-1}$ of a mixture of essential oils and benzoic acid (BMEO; CRINA Poultry Plus-CPP) and $200 \mathrm{mg} \cdot \mathrm{kg}^{-1}$ protease (PRA) (BMEO-PRA). CRINA Poultry Plus contains a mixture of EO compounds (see above) and benzoic acid $\geq 80 \%$. The protease $\left(\right.$ RONOZYME $^{\circledR}$ Proact (PRA), DSM Nutritional Products, Basel, Switzerland) used in this study is a commercial enzyme produced by submerged fermentation of $\mathrm{Ba}$ cillus licheniformis containing transcribed genes from Nocardiopsis prasina.

\section{Sample collection and analyses}

pH measurements in the digestive tract. At the end of the trial, 3 chickens from each subgroup were sacrificed by cervical dislocation. The contents of the crop, gizzard, ileum, caeca and rectum were quantitatively collected. The digesta from each gastrointestinal tract (GIT) segment from three birds was randomly pooled to obtain six replicates per treatment. The ileum was defined as the small intestinal segment caudal to Meckel's diverticulum. The rectum was defined as the segment from the ileo-caecal junction to the end of the GIT. The $\mathrm{pH}$ in the contents of all GIT segments was measured with a combined glass/reference electrode (WTW pH meter, Weilheim, Germany).

Determination of intestinal microbiota. To determine microbial populations, diluted digesta was suspended in pre-reduced salt medium and homogenized for 2 min in $\mathrm{CO}_{2}$-flushed plastic bags using a stomacher homogenizer (Interscience, Saint Nom La Bretéche, France). Subsequently, serial decimal 
dilutions were made, avoiding aeration, using the medium as described by Giannenas et al. (2011). Samples from three birds per subgroup were randomly pooled to obtain six replicates per treatment, incubated under anaerobic conditions at $37^{\circ} \mathrm{C}$ for 48 $\mathrm{h}$ on MRS agar medium (Merck 1.10660, Darmstadt, Germany), and used for the determination of total numbers of lactic acid bacteria, whereas samples incubated under aerobic conditions at $37^{\circ} \mathrm{C}$ for $24 \mathrm{~h}$ on MacConkey agar (Merck 1.05465) were used for the determination of total numbers of coliform bacteria. Results were expressed as base-10 logarithm colonyforming units per gram of ileal or caecal digesta.

Intestinal morphology measurements. Morphometric analysis of the small intestine was evaluated according to Giannenas et al. (2011). During necropsy of 3 chickens from each subgroup, the gastrointestinal tract was removed and the small intestine was divided into three parts: duodenum (from the gizzard outlet to the end of the pancreatic loop), jejunum (from the pancreatic loop to Meckel's diverticulum) and ileum (from Meckel's diverticulum to the ileo-caeco-colic junction). Segments one $\mathrm{cm}$ long were taken from the centre of each part and fixed in $10 \%$ buffered formalin, embedded in paraffin wax, sectioned at $3 \mu \mathrm{m}$ and stained with haematoxylin-eosin. Histological sections were examined with a Nikon phase contrast light microscope coupled with a Microcomp integrated digital imaging analysis system (Nikon Eclipse 80i, Nikon Co., Tokyo, Japan). Images were viewed using a 4x EPlan objective $(40 \times)$ to measure morphometric parameters of intestinal architecture.

For this purpose, three favourably orientated sections cut perpendicularly from villus enterocytes to the muscularis mucosa were selected from each animal and measurements were carried out as follows: villous height $(\mathrm{VH})$ was estimated by measuring the vertical distance from the villous tip to villous-crypt junction level for 10 villi per section; crypt depth (CD) (the vertical distance from the villous-crypt junction to the lower limit of the crypt) was estimated for 10 corresponding crypts per section.

Buffering capacity of the feeds. In order to explain our results, a further in vitro test was performed to determine the buffering capacity of the experimental diets and their ingredients using a WTW pH meter (Weilheim, Germany). A portion of $10 \mathrm{~g}$ feed was placed in a beaker and $100 \mathrm{ml}$ of distilled water were added. The mixture was left to stand for about $30 \mathrm{~min}$, and then titrated with $0.1 \mathrm{~N}$ $\mathrm{HCl}$, under continuous stirring, to reach $\mathrm{pH} 4$ (Florou-Paneri et al., 2001). The microlitres of the acid consumed were used as the units for expressing the buffering capacity of the feeds.
Extraction of proteins. Protein extraction from experimental feeds was performed as previously described (Fullington et al., 1980) with some modifications. Briefly, $1 \mathrm{~g}$ of feed from each group and each corresponding age was suspended in $5 \mathrm{ml}$ of $0.125 \mathrm{M}$ Tris- $\mathrm{HCl}$ buffer $(\mathrm{pH} 8.9)$ containing $0.2 \%$ SDS and $1 \% \quad \beta$-mercaptoethanol and kept under gentle agitation for $30 \mathrm{~min}$. Insoluble material was removed by centrifugation at $12.000 \mathrm{~g}$ for $15 \mathrm{~min}$ at $20^{\circ} \mathrm{C}$. The protein concentration in the resulting supernatants was determined by the Bradford method (Bradford, 1976) using the appropriate controls. All soluble fractions were analysed by electrophoresis in a $12 \%$ SDS polyacrylamide gel (SDS-PAGE).

The concentration of protein in the samples was determined by the Bradford method using bovine albumin as standard. Proteins were separated by electrophoresis in a 10\% (w/v) sodium dodecyl sulphate-polyacrylamide gel (SDS-PAGE) as previously described (Laemmli, 1970). Proteins were stained using Coomassie brilliant blue.

In vitro digestion studies. For the in vitro studies, a heat-stable, formulated (ProAct) product containing 75.000 PROT per $1 \mathrm{~g}$ was used. One PROT is one protease unit and is defined as the amount of enzyme that releases $1 \mu \mathrm{mol}$ of $p$ nitroaniline from $1 \mu \mathrm{M}$ of substrate (Suc-Ala-AlaPro-Phe-pnitroaniline) per min at $\mathrm{pH} 9.0$ and $37^{\circ} \mathrm{C}$ (Fru-Nji et al., 2011). The enzyme was selected as a feed enzyme candidate, because it tolerates low $\mathrm{pH}$ and high temperatures. According to Fru-Nji et al. (2011) at peptic and acidic conditions (pH 2) the enzyme retains more than $90 \%$ of its initial activity after $2 \mathrm{~h}$ at $40^{\circ} \mathrm{C}$.

The performance of the protease was studied in an in vitro model simulating the digestion environ-

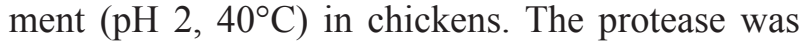
tested for its ability to improve solubilization and digestion of diets. For this reason, $1.5 \mathrm{~g}$ of each feed was dispersed in $15 \mathrm{ml}$ of distilled water. The dispersion was adjusted to $\mathrm{pH} 2.0$ with $2 \mathrm{M} \mathrm{HCl}$ and remained under continued stirring for $30 \mathrm{~min}$. Approximately $5 \mathrm{ml}$ of each dispersion was removed and the protease activity was inhibited by the addition of the phenylmethanesulfonyl fluoride (PMSF) to a final concentration of $1 \mathrm{mM}$. The mixtures were kept on ice for $10 \mathrm{~min}$ and subsequently centrifuged at $12.000 \mathrm{~g}$ for $15 \mathrm{~min}$ at $20^{\circ} \mathrm{C}$. The resulting supernatants were stored at $4^{\circ} \mathrm{C}$ until further use. The rest of the $10 \mathrm{ml}$ dispersion was adjusted to $\mathrm{pH} 8.0$ with $2 \mathrm{M} \mathrm{NaOH}$, stirred at $40^{\circ} \mathrm{C}$ for $30 \mathrm{~min}$ and then centrifuged at $12.000 \mathrm{~g}$ for $15 \mathrm{~min}$ at $20^{\circ} \mathrm{C}$. The protein concentration of all soluble fractions was determined with the Bradford method and analysed by SDS-PAGE. 


\section{Statistical analysis}

Statistical analysis was performed for all experimental data that were subjected to analysis of variance (ANOVA) in the general linear model using the SPSS 17.00 statistical package (SPSS, Inc., Chicago, IL). The homogeneity of the variances was tested. Bacteria numbers were log transformed and then analysed in order to have better homogeneity of variance. When the treatment effects were considered significant at the probability level of $P<0.05$, Duncan's test was applied in order to determine the statistical differences between means. To investigate the effect of benzoic acid on broiler chicken performance, the data was statistically analysed by analysis of variance using the PROC MIXED procedure of SAS (1989) with replication in time considered a random effect. Linear and quadratic orthogonal contrasts were tested using the Contrast statement of SAS. Differences between treatments were considered significant at $P<0.05$.

\section{Results}

\section{Effect of benzoic acid on broiler performance}

The results of Experiment 1 are shown in Table 3 . The final body weight gain (BWG) in birds fed the diet without benzoic acid (C1) and in birds fed the diet with $1000 \mathrm{mg}$ benzoic acid per kg were comparable. Nonetheless, supplementation of the diet with $300 \mathrm{mg} \cdot \mathrm{kg}^{-1}$ benzoic acid increased BWG $(P<0.05)$ compared with both the $\mathrm{C} 1$ and $\mathrm{B} 1000$ groups. Feed conversion ratio (FCR) in the starter period was improved $(P<0.05)$ by benzoic acid supplementation at both levels. In the entire experiment, birds fed the diet with $300 \mathrm{mg}$ benzoic acid per kg presented the lowest FCR $(P<0.05)$ compared with both groups $\mathrm{C} 1$ and $\mathrm{B} 1000$, which had similar FCR values. Mortality did not differ among the experimental groups. The $\mathrm{pH}$ values in the digestive tract were similar among the experimental groups for crop, gizzard, ileum and rectum. In the caecum, in both group B300 and B1000 pH values were lower compared with group $\mathrm{C} 1$. Lactic acid bacteria counts in the crop and in the ileum did not differ among the experimental groups. In the caecum, in both group B300 and B1000, these counts were higher $(P<0.05)$ compared with group $\mathrm{C} 1$. Coliform bacteria tended to decrease in the crop and ileal contents following increased benzoic acid supplementation $(P>0.05)$. In the caecum in both group B300 and B1000, coliform bacteria counts were lower $(P<0.05)$ compared with group $\mathrm{C} 1$.
Table 3. Performance of broiler chickens, pH values and counts of lactic acid bacteria and coliforms in digesta (Experiment 1)

\begin{tabular}{|c|c|c|c|c|c|c|}
\hline \multirow[t]{2}{*}{ Indices } & \multicolumn{3}{|c|}{ Dietary treatment } & \multicolumn{3}{|c|}{ Contrast, p-value } \\
\hline & $\overline{\mathrm{C}^{1}}$ & $\mathrm{~B} 300^{1}$ & $\mathrm{~B} 1000^{1}$ & $\mathrm{SEM}^{2}$ & Linear $^{3}$ & Quadratic $^{3}$ \\
\hline \multicolumn{7}{|c|}{ Body weight gain, $\mathrm{g}$} \\
\hline days $1-14$ & $244^{b}$ & $275^{\mathrm{a}}$ & $258^{\mathrm{ab}}$ & 15.6 & * & ** \\
\hline days $1-42$ & $2144^{b}$ & $2348^{a}$ & $2211^{b}$ & 62.3 & ** & ** \\
\hline Mortality & $2 / 30$ & $1 / 30$ & $1 / 30$ & & NS & NS \\
\hline \multicolumn{7}{|c|}{ Feed conversion ratio (FCR), $\mathrm{kg} \cdot \mathrm{kg}^{-1}$} \\
\hline days $1-14$ & $1.61^{\mathrm{a}}$ & $1.38^{b}$ & $1.41^{\mathrm{b}}$ & 0.01 & * & NS \\
\hline days $1-42$ & $1.86^{\mathrm{a}}$ & $1.71^{\mathrm{b}}$ & $1.84^{\mathrm{a}}$ & 0.05 & ** & * \\
\hline \multicolumn{7}{|l|}{ Digesta pH } \\
\hline crop & 5.39 & 5.26 & 5.24 & 0.042 & NS & NS \\
\hline gizzard & 3.21 & 3.19 & 3.32 & 0.038 & NS & NS \\
\hline ileum & 6.88 & 6.56 & 6.41 & 0.140 & NS & NS \\
\hline caecum & $7.11^{\mathrm{a}}$ & $6.35^{b}$ & $6.31^{b}$ & 0.263 & ** & *** \\
\hline rectum & 7.01 & 6.75 & 6.83 & 0.077 & NS & NS \\
\hline \multicolumn{7}{|c|}{ Lactic acid bacteria, log cfu per $1 \mathrm{~g}$ digesta } \\
\hline crop & 7.29 & 7.61 & 7.55 & 0.098 & NS & NS \\
\hline ileum & 5.86 & 5.95 & 6.05 & 0.056 & NS & NS \\
\hline caecum & $7.46^{\mathrm{b}}$ & $8.05^{\mathrm{a}}$ & $8.18^{\mathrm{a}}$ & 0.242 & $* * *$ & ** \\
\hline \multicolumn{7}{|c|}{ Coliforms, log cfu per $1 \mathrm{~g}$ digesta } \\
\hline crop & 4.18 & 3.76 & 4.03 & 0.128 & NS & NS \\
\hline ileum & 5.60 & 5.41 & 5.33 & 0.080 & NS & NS \\
\hline caecum & $6.16^{a}$ & $5.68^{b}$ & $5.35^{\mathrm{b}}$ & 0.256 & $* *$ & * \\
\hline
\end{tabular}

${ }^{1} \mathrm{C}, \mathrm{B} 300$ and B1000 represent groups of birds fed the basal diet supplemented with benzoic acid at level of 0,300 and $1000 \mathrm{mg} \cdot \mathrm{kg}^{-1}$ of feed respectively

${ }^{2}$ SEM - standard error of the mean, ( $n=6$, number of replicates); ${ }^{3}$ linear and quadratic contrasts were tested: ${ }^{*} P<0.05 ;{ }^{* *} P<0.01$, ${ }^{* * *} P<0.001$; NS - non-significant

a,b means with different superscripts within a row are significantly different $(P \leq 0.05)$

Table 4. Performance of broiler chickens and counts of lactic acid bacteria and coliforms in digesta (Experiment 2)

\begin{tabular}{|c|c|c|c|c|c|}
\hline \multirow{2}{*}{ Indices } & \multicolumn{3}{|c|}{ Dietary treatment } & \multirow{2}{*}{-SEM ${ }^{2}$} & \multirow{2}{*}{$P$-value } \\
\hline & $\overline{\mathrm{C}^{1}}$ & $\mathrm{~T} 30^{1}$ & MEO301 & & \\
\hline \multicolumn{6}{|c|}{ Body weight gain, $g$} \\
\hline days $1-14$ & 241 & 259 & 254 & 5.36 & 0.125 \\
\hline days $1-42$ & $2166^{b}$ & $2184^{b}$ & $2243^{a}$ & 22.69 & 0.003 \\
\hline \multicolumn{6}{|l|}{$\mathrm{FCR}, \mathrm{kg} \cdot \mathrm{kg}^{-1}$} \\
\hline days $1-14$ & 1.54 & 1.48 & 1.45 & 0.026 & 0.087 \\
\hline days $1-42$ & $1.83^{\mathrm{a}}$ & $1.77^{\mathrm{a}}$ & $1.71^{\mathrm{b}}$ & 0.034 & 0.012 \\
\hline Mortality & $2 / 30$ & $2 / 30$ & $1 / 30$ & & NS \\
\hline \multicolumn{6}{|c|}{ Lactic acid bacteria log cfu per $1 \mathrm{~g}$ digesta } \\
\hline crop & 7.16 & 7.63 & 7.71 & 0.18 & 0.227 \\
\hline ileum & 6.26 & 6.13 & 6.19 & 0.041 & 0.108 \\
\hline caecum & $7.58^{\mathrm{b}}$ & $8.11^{\mathrm{a}}$ & $8.19^{a}$ & 0.195 & 0.021 \\
\hline \multicolumn{6}{|c|}{ Coliforms, log cfu per $1 \mathrm{~g}$ digesta } \\
\hline crop & 4.25 & 3.85 & 3.73 & 0.162 & 0.104 \\
\hline ileum & 5.81 & 5.62 & 5.73 & 0.055 & 0.261 \\
\hline caecum & $6.25^{\mathrm{a}}$ & $5.48^{\mathrm{b}}$ & $5.16^{\mathrm{b}}$ & 0.032 & 0.034 \\
\hline
\end{tabular}

${ }^{1}$ groups birds fed either the basal diet $(\mathrm{C})$ or with basal diet supplemented with $30 \mathrm{mg} \cdot \mathrm{kg}^{-1}$ thymol (T30) or with $30 \mathrm{mg} \cdot \mathrm{kg}^{-1}$ of a mixture of essential oils (MEO30)

${ }^{2} \mathrm{SEM}$ - standard error of the mean, ( $n=6$, number of replicates)

$a, b$, means with different superscripts within a row are significantly different $(P \leq 0.05)$ 


\section{Effect of thymol and essential oils on broiler performance}

In Experiment 2, BWG did not differ among the experimental groups during the starter period. At the end of the trial, however, BWG values were higher $(P<0.05)$ in the MEO30 group compared with both the $\mathrm{C} 2$ and T30 groups (Table 4). The FCR in the starter period did not differ, but over the entire experiment, it was lowest in the MEO30 group $(P<0.05)$ compared with both group $\mathrm{C} 2$ and T30. Mortality values did not differ among the experimental groups. Lactic acid and coliform bacteria populations in the crop and in the ileum did not differ among the experimental groups. In the caecum, both group T30 and MEO30 presented higher $(P<0.05)$ lactic acid bacteria populations and lower coliform counts $(P<0.05)$ compared with group $\mathrm{C} 2$.

\section{Effect of combination of essential oil compounds, benzoic acid and protease on broiler performance}

In Experiment 3, significant $(P<0.05)$ differences in BWG were noted among treatments. The cumulative results for BWG, feed consumption, FCR and mortality rate are shown in Table 5 . The BMEO-PRA group presented improved $(P<0.05)$ BWG and FCR values at both time points compared with group C3. Mortality values were similar among the experimental groups. MEO-PRA feed presented significantly lower $(P<0.05)$ buffering capacity and $\mathrm{pH}$ values compared with the $\mathrm{C} 3$ feed (Table 5). The composition of the crop and the ileal microbiota of chickens did not differ. In the caecum, the lactic acid bacteria counts were higher $(P \leq 0.05)$ in the BMEO-PRA-supplemented group compared with group C3. Coliform counts did not differ in the crop and ileum, but were lower in the caecum $(P \leq 0.05)$ in the BMEO-PRA-supplemented group in comparison with group $\mathrm{C} 3$. The mucosal architecture was influenced in the BMEO-PRA-supplemented group in terms of villus height at the jejunum and ileum (Table 5).

\section{Effect of protease on protein extraction and solubilization}

The tested enzyme (ProAct -PRA) was proven to be a purified mono component serine protease which is expressed in B. licheniformis (Figure 1). SDSPAGE of the heat-stable formulated product (Figure 1) revealed a single band at approximately $20 \mathrm{kDa}$ verifying the purity of the enzyme used in this study.

To investigate the effect of protease on protein extraction (solubilization) from the tested feed, as well as its digestibility, the protein pattern of the
Table 5. Performance of broiler chickens, buffering capacity of the diets, intestinal microbiota, and intestinal morphology (Experiment 3)

\begin{tabular}{|c|c|c|c|c|}
\hline \multirow{2}{*}{ Indices } & \multicolumn{2}{|c|}{ Dietary treatment } & \multirow{2}{*}{ - SEM ${ }^{2}$} & \multirow{2}{*}{$P$-value } \\
\hline & $\overline{\mathrm{C}^{1}}$ & BMEO-PRA $^{1}$ & & \\
\hline \multicolumn{5}{|l|}{ Body weight gain, $g$} \\
\hline days $1-14$ & $251^{b}$ & $298^{a}$ & 23.6 & 0.021 \\
\hline days $1-42$ & $2204^{b}$ & $2368^{a}$ & 85.3 & 0.009 \\
\hline \multicolumn{5}{|l|}{ Feed conversion ratio, $\mathrm{kg} \cdot \mathrm{kg}^{-1}$} \\
\hline days $1-14$ & $1.55^{\mathrm{a}}$ & $1.35^{b}$ & 0.122 & 0.019 \\
\hline days $1-42$ & $1.83^{\mathrm{a}}$ & $1.64^{b}$ & 0.095 & 0.022 \\
\hline Mortality & $2 / 30$ & $1 / 30$ & & NS \\
\hline \multicolumn{5}{|l|}{ Buffering capacity of the diets, $\mathrm{m}^{3}$} \\
\hline days $1-14$ & $51.2^{\mathrm{a}}$ & $40.2^{b}$ & 5.61 & 0.001 \\
\hline days $15-42$ & $47.5^{\mathrm{a}}$ & $32.1^{\mathrm{b}}$ & 7.23 & 0.000 \\
\hline \multicolumn{5}{|l|}{$\mathrm{pH}$ values of the diets } \\
\hline days $1-14$ & $6.41^{\mathrm{a}}$ & $6.18^{b}$ & 0.113 & 0.008 \\
\hline days $15-42$ & $6.29^{\mathrm{a}}$ & $6.16^{b}$ & 0.072 & 0.012 \\
\hline \multicolumn{5}{|c|}{ Lactic acid bacteria, log cfu per $1 \mathrm{~g}$ digesta } \\
\hline crop & 7.11 & 7.18 & 0.035 & 0.136 \\
\hline ileum & 5.84 & 5.98 & 0.070 & 0.252 \\
\hline caecum & $7.55^{\mathrm{b}}$ & $8.64^{\mathrm{a}}$ & 0.531 & 0.033 \\
\hline \multicolumn{5}{|l|}{ Coliforms, log cfu per $1 \mathrm{~g}$ digesta } \\
\hline crop & 4.23 & 3.95 & 0.140 & 0.224 \\
\hline ileum & 5.55 & 5.28 & 0.135 & 0.187 \\
\hline caeca & $5.98^{\mathrm{a}}$ & $4.91^{\mathrm{b}}$ & 0.535 & 0.024 \\
\hline \multicolumn{5}{|l|}{ Intestinal morphology } \\
\hline \multicolumn{5}{|l|}{ Duodenum } \\
\hline villous height, $\mu \mathrm{m}$ & 1910 & 1992 & 41.6 & 0.098 \\
\hline crypt depth, $\mu \mathrm{m}$ & 181 & 182 & 0.56 & 0.216 \\
\hline $\begin{array}{l}\text { villous height to crypt depth } \\
\text { ratio }\end{array}$ & 10.5 & 10.9 & 0.26 & 0.116 \\
\hline \multicolumn{5}{|l|}{ Jejunum } \\
\hline villous height, $\mu \mathrm{m}$ & $1458 .^{b}$ & $1545^{a}$ & 44.3 & 0.042 \\
\hline crypt depth, $\mu \mathrm{m}$ & 141 & 144 & 1.65 & 0.233 \\
\hline $\begin{array}{l}\text { villous height to crypt depth } \\
\text { ratio }\end{array}$ & 10.3 & 10.7 & 0.32 & 0.287 \\
\hline \multicolumn{5}{|l|}{ Ileum } \\
\hline villous height, $\mu \mathrm{m}$ & $945^{\mathrm{a}}$ & $993^{b}$ & 23.6 & 0.031 \\
\hline crypt depth, $\mu \mathrm{m}$ & 121 & 101 & 10.2 & 0.048 \\
\hline $\begin{array}{l}\text { villous height to crypt depth } \\
\text { ratio }\end{array}$ & 7.78 & 9.75 & 1.02 & 0.055 \\
\hline
\end{tabular}

${ }^{1}$ Groupsofbirdsfedeitherthebasaldiet(C)orwithbasaldietsupplemented with a mixture of benzoic acid, essential oils and protease (BMEO-PRA).

${ }^{2}$ Standard error of the mean, ( $n=6$, number of replicates)

${ }^{3} \mathrm{ml} 0.1 \mathrm{~N} \mathrm{HCl}$ required to acidify $10 \mathrm{~g}$ diet dispersed in $100 \mathrm{ml}$ distilled water to $\mathrm{pH}$;

$a, b$ means with different superscripts within a row are significantly different $(P \leq 0.05)$

extracted proteins from the tested feeds was visualized in the SDS-PAGE of Figure 2 (I). Proteinband patterns of both control and BMEO-PRA diets were identical within MW 10-180 kDa (the range of standards of protein MW markers). In both groups, 10 clear bands were visualized, while 3 major bands at approximately 70,35 , and $25 \mathrm{kDa}$ were detected. In addition there were some unclear (minor) bands that might be some low content proteins. 


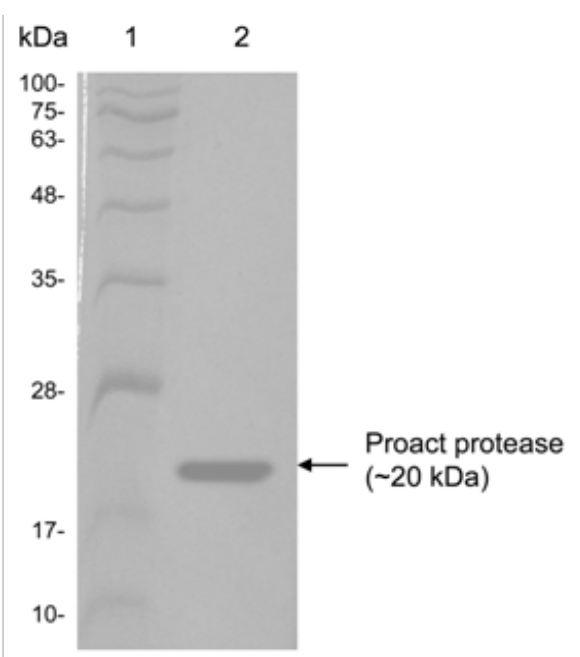

Figure 1. SDS-PAGE analysis of RONOZYME ${ }^{\circledR}$ ProAct. Lanes 1: molecular weight markers; 2: PRA protease $(20 \mu \mathrm{g})$

Samples of each diet after incubation at $\mathrm{pH} 2$ and $\mathrm{pH} 8$ were analysed by SDS-PAGE, while the protein content of each sample was also determined. The results revealed that both protein digestion and protein solubilization were significantly increased in samples incubated with protease compared with the control samples (Figure 2 (II) and (III), respectively). As illustrated in Figure 2 (II), addition of protease and incubation at $\mathrm{pH} 2$ for 30 min digested all major proteins (MW 74, 70, 35, $25 \mathrm{kDa}$, see Figure 2 ) in the samples since their bands disappeared (Figure 2 (II)). It is also clear that protease did not completely digest (during the time of the experiment, 30 $\mathrm{min}$ ) the sample to amino acids, since a major band of a peptide of about $8 \mathrm{KDa}$ was still present (Figure 2 II; Samples $\mathrm{A}+$ and $\mathrm{B}+$ ). The continuation of digestion at $\mathrm{pH} 8$ that mimics the natural process (stomach then intestines) seems to extract more proteins from feed (Figure 2 II.)

Moreover, the positive effect of protease on protein solubilization (extraction from feeds) is illustrated in Figure 2 (III). After incubation at $\mathrm{pH}$ 2.0 for 30 min and continued stirring, the soluble protein concentration in control samples of starter (A) and grower diets (B) were $4.78 \mathrm{mg} \cdot \mathrm{ml}^{-1}$ and $4.47 \mathrm{mg} \cdot \mathrm{ml}^{-1}$, respectively (Figure 2 III). These numbers were significantly increased by $17 \%$ $\left(5.59 \mathrm{mg} \cdot \mathrm{ml}^{-1}\right)$ and $13 \%\left(5.09 \mathrm{mg} \cdot \mathrm{ml}^{-1}\right)$, respectively by the addition of protease in the starter $(\mathrm{A}+)$ and grower $(\mathrm{B}+)$ diet of the BMEO-PRA group. Moreover, when the incubation and stir-

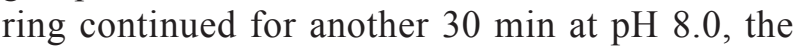
soluble protein concentration of the control starter (A) and grower (B) diets was $5.43 \mathrm{mg} \cdot \mathrm{ml}^{-1}$ and $4.91 \mathrm{mg} \cdot \mathrm{ml}^{-1}$, respectively. In addition, the presence of protease in the BMEO-PRA diets further increased the protein concentration to 5.92
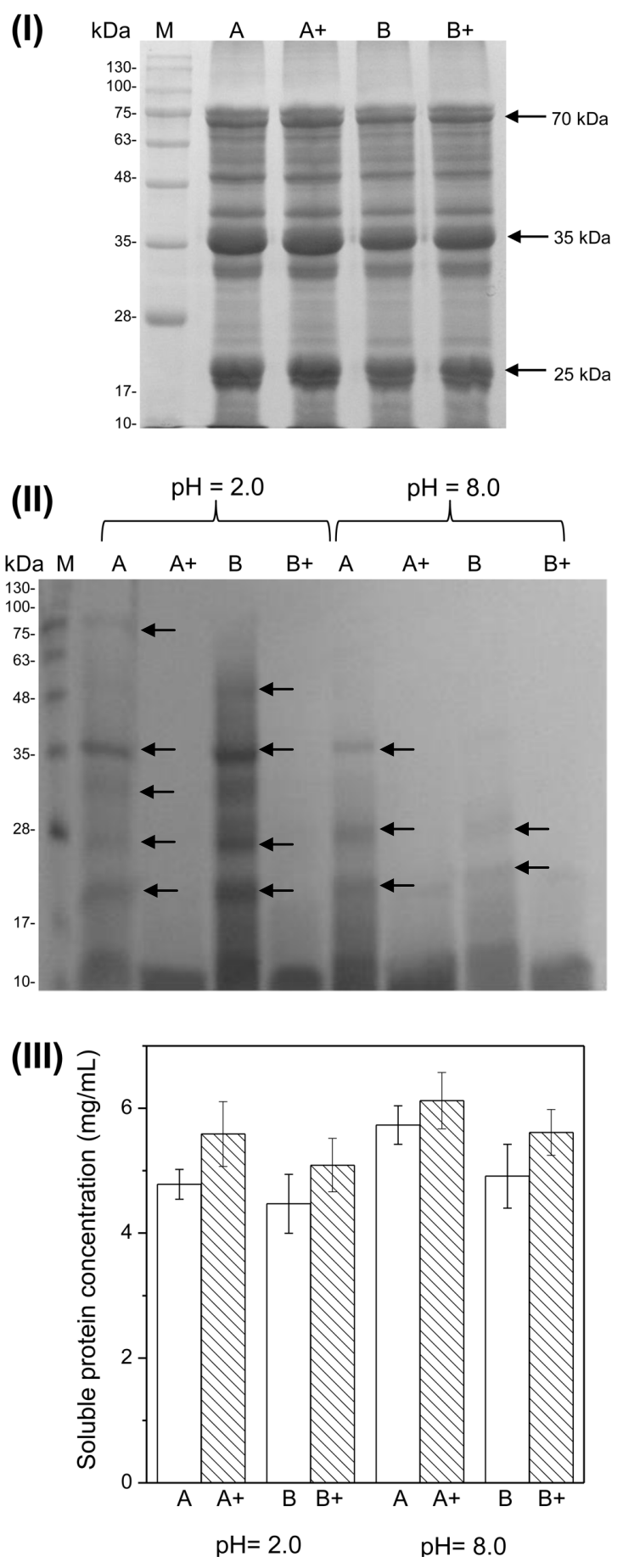

Figure 2. Analysis of protein in samples of starter diet control and MEO-PRA ( $A$ and $A+$, respectively) and samples of grower diet control and MEO-PRA ( $\mathrm{B}$ and $\mathrm{B}+$, respectively

(I) SDS-PAGE patterns of experimental feeds. The three major bands at 70,35 and $25 \mathrm{kDa}$ are indicated with arrows. Lane M: molecular weight markers

(II) Effect of protease on protein digestion. Feeds were incubated at $\mathrm{pH} 2.0$ for $30 \mathrm{~min}$ at $40^{\circ} \mathrm{C}$ and subsequently at $\mathrm{pH} 8.0$ for another 30 $\min$ at $40^{\circ} \mathrm{C}$. Insoluble materials were removed by centrifugation. Reduction of protein bands indicates digestion of particular protein

(III) Solubilization of proteins from solid samples (feeds) at different conditions. Feeds were incubated at pH 2.0 for $30 \mathrm{~min}$ at $40^{\circ} \mathrm{C}$ and subsequently at $\mathrm{pH} 8.0$ for another $30 \mathrm{~min}$ at $40^{\circ} \mathrm{C}$. Concentrations of soluble protein were determined with Bradford method. Arrows indicate the differences between control samples and samples containing protease 
$\mathrm{mg} \cdot \mathrm{ml}^{-1}$ and $5.21 \mathrm{mg} \cdot \mathrm{ml}^{-1}$ for starter $(\mathrm{A}+)$ and grower $(\mathrm{B}+)$ diets, respectively.

The increase of solubility indicates that more feed protein is available for digestion. The increase in protein concentration in the above BMEO-PRA samples should not be associated with the addition of protease. The amount of protease added to both samples (A and B) was negligible, corresponding to a $0.1 \%$ increase of the protein concentration of both original samples.

\section{Discussion}

Although it has been common practice in animal farming to add organic acids to feeds for both their preservative effect and the positive influence they have on growth and feed conversion ratio (Falkowski and Aherne, 1984), literature data on the response of broiler chickens to dietary benzoic acid are limited.

Our findings are in agreement with previous experiments (Jozefiak et al., 2010). According to these authors, benzoic acid reduction of the growth rate when fed at higher than $0.1 \%$ inclusions can be explained by its metabolic pathway - conjugation with ornithine. They further reported that the domestic fowl excreted benzoic acid and other aromatic acids such as pyromucic, phenylacetic, p-nitrophenylacetic and picolinic acids, as well as nicotinic acid conjugated with ornithine. For this reason, feeding benzoic acid could result in an arginine deficiency because dietary arginine is the source of ornithine in the fowl. Characteristically poor feathering is generally observed in case of arginine deficiency in young chickens. Besides organic acids, essential oil compounds are widely used in monogastric animals to improve performance via modulation of the gut microbiota (Franz et al., 2010). In a meta-analysis it was demonstrated that the eubiotic feed additive (CPP), which has also been used in our work, did improve performance of broiler chickens under semi-commercial conditions (Weber et al., 2012).

The literature inconsistency might also be due to differences in the buffering capacity value of the used diets. The buffering capacity value indicating the amount of acid needed to lower the $\mathrm{pH}$ of a feed to a certain value is important because it affects the course of digestion. High buffering capacity values in feeds pose higher risks for young animals, which have limited capacity to secrete gastric acid. When using feeds with a high buffering capacity, the gastric $\mathrm{pH}$ will remain high, impairing protein digestibility. Undigested protein will reach the lower digestive tract where excessive protein fermentation may occur, leading to formation of toxic biogenic amines (Sturkie, 1976). In addition, poultry feeds with high buffering capacity may result in proliferation of harmful bacteria in the digestive tract.

Table 5 illustrates that the source used to supply the mineral requirements to the broiler diets could largely influence their acidic/basic balance and, consequently, their buffering capacity. As shown in Table 2, however, limestone, sodium bicarbonate and the trace-mineral premix levels were the same in both diets, so the difference in buffering capacity of the diets is connected rather with the additives.

Dietary supplementation of benzoic acid, essential oils and protease shifted microbiota populations by increasing Lactobacillus loads. It has been reported that lactic acid-producing bacteria may improve gastrointestinal function, feed digestibility and animal performance (Rehman et al., 2006). It is suggested that the establishment of Lactobacillus spp. prevents the colonization of pathogenic bacteria by competitive exclusion (van der Wielen et al., 2002). Lactobacilli and bifidobacteria compete against potential pathogens for nutrients and binding sites, thereby reducing the intestinal population of pathogens. Furthermore, lactobacilli and bifidobacteria produce organic acids and other bactericidal substances (Jin et al., 1998), all of which can suppress the colonization of the intestine by pathogenic bacteria. It is possible that benzoic acid and essential oils favoured the growth of lactobacilli and bifidobacteria populations and inhibited that of coliforms.

In this study, a significant increase in jejunal and ileal villus height was noted. The height of intestinal villi is connected with the capacity of the bird to absorb nutrients from feed. Longer villi are typically associated with excellent gut health and high absorptive efficiency. Cook and Bird (1973) reported that shorter villi and deeper crypts are found when the counts of pathogenic bacteria in the gastrointestinal tract are increased (Schneeman, 1982). The structure of the intestinal mucosa can reveal some information on gut health. Stressors that are present in the digesta can lead relatively quickly to changes in the intestinal mucosa, due to the close proximity of the mucosal surface and the intestinal content. Changes in intestinal morphology, such as shorter villi and deeper crypts have been associated with the presence of toxins or higher tissue turnover (Miles et al., 2006).

Poultry naturally produce enzymes to aid the digestion of feed nutrients. The benefits of using feed enzymes in poultry diets include not only enhanced bird performance and feed conversion but 
also fewer environmental problems due to reduced output of excreta. Proteases are added to feed with the purpose of increasing dietary protein hydrolysis, thus enabling improved nitrogen utilization. When animals utilize nitrogen better, it is possible to decrease the protein content in diet and, in turn, also reduce the content of nitrogen in manure (Oxenboll et al., 2011). Our in vitro experiments illustrate that the novel serine protease improved the solubilization (extraction) and digestion of crude proteins of experimental feeds. This observation is in good agreement with the findings of Fru-Nji et al. (2011) showing that protease enhances protein and amino acid digestibility.

\section{Conclusions}

In conclusion, feed additives such as enzymes, EOs and benzoic acid and their combination can improve the growth performance of broiler chickens. Our results suggest that the combination of benzoic acid with essential oil compounds together with a pure protease exerted a positive effect on the performance of broiler chickens and improved gut integrity and some intestinal microbiota. In vitro experiments revealed that the addition of protease increased feed protein solubilization and addition of benzoic acid reduced the buffering capacity of the feed, together offering significant support for birds in digesting ingested feed.

\section{References}

Acamovic T., 2001. Commercial application of enzyme technology for poultry production. World Poultry Sci. J. 57, 225-242

Amaechi N., Anueyiagu C.F., 2012. Effect of dietary benzoic acid supplementation on growth performance and intestinal wall morphology of broilers. J. Anim. Feed Res. 2, 401-404

Amerah A.M., Peron A., Zaefarian F., Ravindran V., 2011. Influence of whole wheat inclusion and a blend of essential oils on the performance, nutrient utilization, digestive tract development and ileal microbiota profile of broiler chickens. Brit. Poultry Sci. 52, 124-132

Bradford M.M., 1976. A rapid and sensitive method for the quantitation of microgram quantities of protein utilizing the principle of protein-dye binding. Anal. Biochem. 72, 248-254

Cook R.H., Bird F.H., 1973. Duodenal villus area and epithelial cellular migration in conventional and germ-free chicks. Poultry Sci. $52,2276-2280$

Eidelsburger U., Kirchgessner M., 1994. Effect of organic acids and salts in the feed on fattening performance of broilers. Arch. Geflügelk. 58, 268-277

Falkowski J., Aherne F.X., 1984. Fumaric acid and citric acid as feed additives in starter pig nutrition. J. Anim. Sci. 58, 935-938

Florou-Paneri P., Christaki E., Botsoglou N.A., Kalousis A., Spais A.B., 2001. Performance of broilers and the hydrogen ion concentration in their digestive tract following feeding of diets with different buffering capacities. Arch. Geflügelk. 65, 1-5
Franz C., Baser K.H.C., Windisch W., 2010. Essential oils and aromatic plants in animal feeding - a European perspective. A review. Flavour Frag. J. 25, 327-340

Fru-Nji F., Kluenter A.M., Fischer M., Pontoppidan K., 2011. A feed serine protease improves broiler performance and increases protein and energy digestibility. J. Poultry Sci. 48, 239-246

Fullington J.G., Earl W.C., Kasarda D.D., 1980. Quantitative SDSPAGE of total protein from different wheat varietie. J. Sci. Food Agr. 31, 43-53

Giannenas I., Florou-Paneri P., Botsoglou N., Christaki E., Spais A.B., 2005. Effect of supplementing feed with oregano and/or atocopheryl acetate on growth of broiler chickens and oxidative stability of meat. J. Anim. Feed Sci. 14, 521-535

Giannenas I., Florou-Paneri P., Papazahariadou M., Christaki E., Botsoglou, N.A., Spais A.B., 2003. Effect of dietary supplementation with oregano essential oil on performance of broilers after experimental infection with Eimeria tenella. Arch. Tierernähr. 57, 99-106

Giannenas I., Tsalie E., Chronis E., Mavridis S., Tontis D., Kyriazakis I., 2011. Consumption of Agaricus bisporus mushroom affects the performance, intestinal microflora composition and morphology, and antioxidant status of turkey poults. Anim. Feed Sci.Tech. 165, 218-229

Jin L.Z., Ho Y.W., Abdullah N., Jalaludin S., 1998. Growth performance, intestinal microbial populations, and serum cholesterol of broilers fed diets containing Lactobacillus cultures. Poultry Sci. 77, 1259-1265

Jozefiak D., Kaczmarek S., Rutkowski A., 2010. The effects of benzoic acid supplementation on the performance of broiler chickens. J. Anim. Physiol. Anim. Nutr. 94, 29-34

Laemmli U.K., 1970. Cleavage of structural proteins during the assembly of the head of bacteriophage T4. Nature 227, 680-685

Leeson S., Caston L.J., 1996. Response of laying hens to diets varying in crude protein or available phosphorus. J. Appl. Poultry Res. 5, 289-296

Miles R.D., Butcher G.B., Henry P.R., Littell R.C., 2006. Effect of antibiotic growth promoters on broiler performance, intestinal growth parameters, and quantitative morphology. Poultry Sci. $85,476-485$

Oxenboll K.M., Pontoppidan K., Fru-Nji F., 2011. Use of a protease in poultry feed offers promising environmental benefits. Int. J. Poultry Sci. 10, 842-848

Partanen K., Mroz Z., 1999. Organic acids for perfrormance enhancement in pig diets. Nutr. Res. Rev. 12, 117-145

Rehman H., Böhm J., Zentek J., 2006. Effects of diets with inulin and sucrose on the microbial fermentation in the gastrointestinal tract of broilers. Proc.Soc. Nutr. Physiol. 15, 155-158

SAS, 1989. SAS User's Guide. SAS Institute. Cary, NC

Schneeman B.D.P., 1982. Pancreatic and digestive function, in: Vahuoung, GV, Kritchevsky D: Dietary Fibre in Health and Disease. Plenum Press, New York.

Sturkie P.D. (ed.), 1976. Protein metabolism. In: Avian Physiology, New York.

van der Wielen P.W., Lipman L.J., van Knapen F., Biesterveld S., 2002. Competitive exclusion of Salmonella enterica serovar Enteritidis by Lactobacillus crispatus and Clostridium lactatifermentans in a sequencing fed-batch culture. Appl. Environ. Microbiol. 68, 555-559

Weber G.M., Michalczuk M., Huyghebaert G., Juin H., Kwakernaak C., Gracia M.I., 2012. Effects of a blend of essential oil compounds and benzoic acid on performance of broiler chickens as revealed by a meta-analysis of 4 growth trials in various locations. Poultry Sci. 91, 2820-2828 